\title{
Effects of Long-Term Exposure of Tuffs to High-Level Nuclear Waste Repository Conditions: Final Report
}
J. D. Blacic
D. T. Vaniman
D. L. Bish
C. J. Duffy
R. C. Gooley

\section{MASTER}

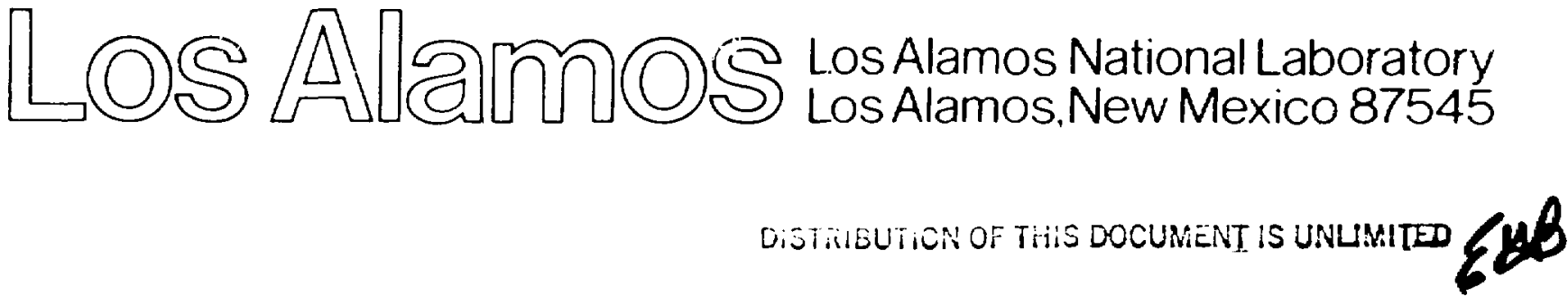


CONTENTS

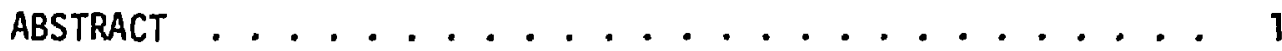

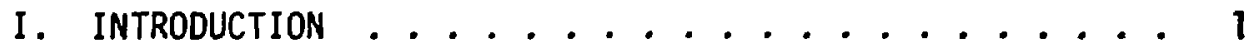

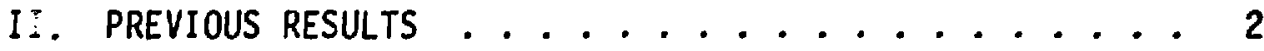

A. Test Method ............. 2

B. Summary of Previous Results ......... 4

III. INVESTIGATION OF POSSIBLE PETROLOGIC AND MINERALOGIC

CHANGES AT HIGH-LEVEL NUCLEAR. WASTE REPOSITORY

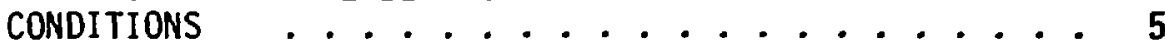

A. Methods ............... 6

B. Results of Petrologic and Mineralogic Studies . . 8

C. Summary of Observations ......... 16

IV. INVESTIGATION OF POSSIBLE MATRIX PERMEABILITY CHANGES 18

A. introduction ............... 18

B. Test Method ............. 19

C. Results .............. 19

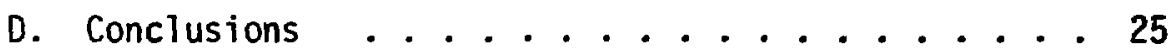

v. IINAL SUMMARY AND CONCLUSIONS ......... 25

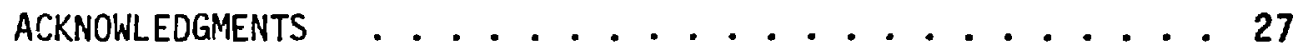

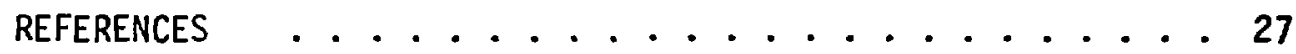
APPENDIX: ELECTRON PROBE ANALYSES OF ZEOLITES AND CLAYS . . 29 
EFFECTS OF LONG-TERM EXPOSURE OF TUFFS TO HIGH-LEVEL NUCLEAR WASTE REPOSITORY CONOITIONS: FIMAL REPORT

by

J. D. Blacic, D. T. Vaniman, D. L. Bish, C. J. Duffy, and R. C. Gooley

\section{ABSTRACT}

We have performed exploratory tests to investigate the effects of extended exposure of tuffs from Yucca Mountain, Mevada, to temperatures and pressures similar to those that will be encountered in a high-level nuclear waste repository. In a preliminary report we described statistically significant changes in strength properties and generally minor changes in porosity and grain density. In the present report we describe additional measurements that indicate possible changes in permeability (in one tuff type) after exposure for 2 to 6 months at temperatures from 80 to $180^{\circ} \mathrm{C}$, confining pressures of 9.7 and $19.7 \mathrm{MPa}$, and water pore pressures of 0.5 and 19.7 $\mathrm{MPa}$. Mineralogic examinations have established reactions involving dissolution of silica and feldspar minerals and possible conversion of clinoptilolite to mordenite. We conclude that rock properties important to the operation of a nuclear waste repository in tuff are likely to change over tine when exposed to simulated repository conditions, and the details of these time-dependent processes should be investigated further.

\section{INTRODUCTION}

The rock environment of a high-level nuclear waste repository will be subjected to elevated temperature and stress in the presence of water. These hot, wet conditions have the potential of causing irreversible changes in the thermomechanical properties of the host rock that are likely to occur only slowly over time: in effect, a low-grade metamorphism. The thermoinechanical properties of the host rock are essential inputs to the design of a repository, and therefore, some estimate of how these properties may change as a result of the conditions induced by the waste heat source is needed. The structural and mineralogic changes that we suspect may occur are very complicated and ultimately may require more sophisticated investigations. 
Nevertheless, it is advisable to carry out exploratory tests in order to focus more detailed studies at a later stage.

The evaluation of tuff as a repository host rock is being performed by the Nevada Nuclear Waste Storage Investigations (NNWSI) and is managed by the US Department of Energy's Nevada Operations Office. The tuffs specifically under study are those of Yucca Mountain, located near the southwestern edge of the Nevada Test Site (NTS) in Nye County, south-central Mevada. Yucca Mountain is one of s:veral sites in the country being considered for the development of a miner repository to store high-level radioactive waste. Descriptions of this sitn and of the drill cores discussed in this report can be found in Blacic et al., 1 Sperigler et al., ${ }^{2}$ Bish et al ., ${ }^{3}$ and Caporuscio et al.$^{4}$

\section{PREVIOUS RESULTS}

We designed an experiment to test a large number of samples at one time by an extended exposure to conditions expected near a waste repository. Preliminary results of these experiments were summarized by Blacic et al. 1 The individual tests were designed to cover a range of temperature and pressure conditions simulating varying distances from the waste canister. Because the properties of tuffs vary substantially with lithology, a range of tuff "types" covering varying degrees of welding and postdeposition mineralization were chosen. The types chosen represent two major tuff mineralogies. Devitrified tuff (tuff formed mostly of feldspar and silica minerals) is represented mostly by samples from the Topopah Spring Member of the Paintbrush Tuff but also by samples from the Bullfrog and Tram Members of the Crater Flat Tuff, with the Tram Member containing minor amounts of zeolite as well as the devitrification minerals. Zeolitized tuff is represented by the clinoptilolite-mordenite tuff of Calico Hills.

A. Test Method

Details of the test method are given in the preliminary report. ${ }^{1}$ A brief description follows. Samples were $2.54-\mathrm{cm}-\mathrm{diam}$ by $6.5-\mathrm{cm}-1$ ong cylinders taken from core holes UE-25a\#I and USW G-1 from Yucca Mountain at the Nevada Test Site. Samples were taken from the four stratigraphic units mentioned above: (1) Topopah Spring Member of the Paintbrush Tuff in drill hole UE-25a\#1; (2) tuffaceous beds of Calico Hills in drill hole UE-25a11; (3) Bullfrog Member of the Crater Flat Tuff in drill hole USW G-1; and (4) Tram Member of the Crater Flat Tuff in drill hole USW G-1. See Refs. 2 and 3 for a description of the 
general lithology and mineralogy/petrology of these units. Control samples came from the same piece of core as the test sample, in most cases cut side-by-side. Each test sample was contained in an individual pressure vessel and subjected to the following range of conditions: temperature, $80-180^{\circ} \mathrm{C}$; confining pressure, 9.7-19.7 Ma; water pore pressure, 0.5-19.7 MPa; duration, 2-6 months. Table I, reproduced from the preliminary report, ${ }^{1}$ gives the combinations of test variables used for each sample.

The test times of 2-6 months ware selected arbitrarily as being hopefully long enough to establish some of the sluggish mineralogic reactions that we anticipated might occur. in retrospect, as will be made clear below, some reactions for which we only obtained the barest indications will undoubtedly be more extensive at extended times. Also, there is no guarantee, of course, that properties that did not change in these tests will not at later times. This problem is discussed in the summary.

As noted above, the procedure was to measure a range of thermomechanical properties in control samples and then to measure the same properties in the samples exposed to the test conditions. These are designated as "before" and "after" measurements. A11 properties were measured at ambient conditions (room temperature and pressure). This procedure was dictated by the philosophy of the test, namely to look for irreversible changes in key properties. However, as a result, these measurements should not be considered as substitutes for measurements at higher temperature and pressure conditions required for engineering data. More detailed measurements at test conditions are required for this. In the preliminary report ${ }^{1}$ we give the results for tensile

TABLE I

KEY TO TEST CONDITIONS

\begin{tabular}{|c|c|c|c|c|}
\hline Test * & $\begin{array}{c}\text { Temperature } \\
\left({ }^{\circ} \mathrm{C}\right)\end{array}$ & $\begin{array}{c}\text { Confining Pressure } \\
\text { (Mad) }\end{array}$ & $\begin{array}{l}\text { Pore Pressure } \\
\text { (MPa) }\end{array}$ & $\begin{array}{l}\text { Duration } \\
(\mathbf{m o})\end{array}$ \\
\hline $\begin{array}{r}1 \\
2 \\
3 \\
4 \\
5 \\
6 \\
7 \\
8 \\
9 \\
10\end{array}$ & $\begin{array}{r}80 \\
80 \\
120 \\
120 \\
120 \\
120 \\
180 \\
180 \\
120 \\
120\end{array}$ & $\begin{array}{r}19.7 \\
9.7 \\
19.7 \\
9.7 \\
19.7 \\
9.7 \\
9.7 \\
9.7 \\
19.7 \\
9.7\end{array}$ & $\begin{array}{r}5.0 \\
0.5 \\
19.7 \\
0.5 \\
19.7 \\
9.7 \\
9.7 \\
9.7 \\
19.7 \\
9.7\end{array}$ & $\begin{array}{l}6 \\
6 \\
5.5 \\
5.5 \\
2.5 \\
2.5 \\
3.5 \\
3.5 \\
2 \\
2\end{array}$ \\
\hline
\end{tabular}


strength, uniaxial compressive strength, grain density, and porosity. These

results are summarized in Section II.B. In the present report we detail the results for perineability, mineralogic, and petrologic changes.

B. Summary of Previous Results

The previous results are summarized below in terms of the individual rock units. A problem inherent in the evaluation of the properties of tuffs is sample inhomogeneity. We tried to reduce this problem by taking samples for "before" and "after" comparisons side-by-side from the same section of core in the belief that this would compensate for the large vertical variations in properties that are aiparent from the measurements. However, for the relatively small samples used in this study, local inhomogeneities (for example, small lithic or pumice fragments) can affect the validity of any apparent changes. Ideally, a large number of repeat measurements are desirable. An attempt to do this in the preliminary report was carried out by using a t-significance test. But in view of the small number of repeat measirements, the conclusions are, to a degree, subjective.

Topopah Spring Member: After exposure to the range of conditions used, tensile strength decreased up to $45 \%$ and uniaxial compressive sirength decreased up to $25 \%$. Porosity increased up to $20 \%$ after exposure at $80^{\circ} \mathrm{C}$ but decreased up to $25 \%$ after exposure to higher temperatures. Grain dersities remained virtually unchanged.

Calico Hills Unit: After exposure to the range of conditions used, tensile strength increased up to $16 \%$ and uniaxial compressive strength decreased up to $25 \%$. Both porosity and grain density increased up to $20 \%$.

Bullfrog Member: Tensile strength decreased slightly after exposure at $120^{\circ} \mathrm{C}$ and increased slightly after exposure to $180^{\circ} \mathrm{C}$. Uniaxial compressive strength decreased up to $17 \%$ after $120^{\circ} \mathrm{C}$ exposure but unexpectedly increased up to $31 \%$ in samples exposed to $180^{\circ} \mathrm{C}$. Porosity increased slightly after $120^{\circ} \mathrm{C}$ but decreased slightiy after $180^{\circ} \mathrm{C}$. Grain densities were unchanged.

Tram Member: Tensile strength decreased up to $30 \%$ after exposure at $120^{\circ} \mathrm{C}$ but instead increased up to $36 \%$ after $180^{\circ} \mathrm{C}$ exposure. Uniaxial compressive strength changes were similar to those observed for Bullfrog tuff but were judged to be statistically inconclusive. Porosity decreased slightly and grain densities were unchanged.

The overall conclusion reached in the preliminary report was that there appear to be large and statistically significant (i.e., nonranciom according to 
the $t$ test) changes in tensile and uniaxial compressive strength after extended exposure to temperature and pressure conditions possible in the nearfield region of a repository. With the exception of the Calico Hills tuff, porosities and grain densities were essentially unaffected. There appears, however, to be a qualitative change in behavior at $120^{\circ} \mathrm{C}$. In several instances the sign of the observed changes after exposure at or below $120^{\circ} \mathrm{C}$ was reversed after exposure at $180^{\circ} \mathrm{C}$. We speculate that this may reflect some as yet unidentified change in the mechanisins responsible for the changes. It must be noted that all tests described here were performed at sufficiently high fluid pressures to maintain pore fluids in the liquid state. Since local boiling may occur in the near field even above the water table where tuffs at Yucca Mountain are $80 \%$ satirated or greater, these tests are conservative in the sense that near-field dehydration effects are not considered.

III. INVESTIGATION OF POSSIBLE PETROLOGIC AND MINERALOGIC CHANGES AT HIGHLEVEL NUCLEAR HASTE REPOSITDRY CONDITIONS

Petrologic and mineralogic studies of samples exposed to simulated highlevel nuclear waste repository conditions may help to explain the changes in bulk mechanical properties noted in the preliminary report. In many cases the mechanical test results indicate a statistically significant change in properties in side-by-side samples, even though there is no apparent change in sample mineralogy or visible grain-boundary relations. The abundance of such cases suggests that the causative changes are either too subtle or too localized to be observed by the methods utilized in this study. Subtlety of change is not unlikely in experiments run at low temperatures over periods of a few months since, under such conditions, the changes in mechanical properties may be due to modification of the surface properties of mineral grains, rather than to gross dissolution and/or recrystallization. In the silicic tuffs studied here, grains affected occur in a vast matrix of submicron-sized crystals, difficult to investigate by microscope or even by electron microbeam techniques.

The possibility of localized changes presents a different problem. Tuff is a complex rock type, composed of pyroclastic particles of widely varying grain size and composition. In the tuffs of interest here, these particles include pumice fragments that range up to 2 to $3 \mathrm{~cm}$ in diameter. Pumice fragments this large could be an obvious problem in test samples that are 2.5 
$\mathrm{cm}$ in diameter and $6.5 \mathrm{~cm}$ long. As mentioned previously, one well-placed pumice or lithic frayment could yreatly alter the physical properties ot a small tuff sample. Localized fractures or lithopnysal cavities may lead to similar problems. These problems nave been considered and nanalea by the t-test methods described earlier. 1 Extensive statistical testing, nowever, was not possible and the atter-test occurrence of medns for physical properties outside the 90\% t-test probability linits cannot be ruled out.

Sone difterences !n strength between major tuft units betore hydrothermal exposure are explained by differences in welding. For example, the densely welded Topopah Suring unit has tensile and compressive strenyths that are roughly 900\% and 500\% greater, respectively, than the tensile and compressive strengths of the poorly weldea Bullfroy unit. 1 Ditterences in mechanical properties between units may also be related to secondary mineralization. For example, the zeolitizea Calico Hils unit has compressive ana tensile strengths that are roughly $100 \%$ greater than in the Bullfrog unit, even though both units are poorly welded to non-welded. Un a tiner scale, alterences in mechanical properties within a single tuff unit can be related to groundnass textures. The Tram unit at 2944.6 to $2 y 4 b .0 \mathrm{ft}$ has a tensile strength $30 u \%$ greater and a compressive strength $100 \%$ greater than the same rock at 2772.7 to $2773.3 \mathrm{tt} .1$ The rocks at both depths are partially welded and have similar mineralogy and pumice content. The difference between the samples from these two depths apparently results from the relations between groundmass crystals. The relatively weak sample at 2772.7 to $2773.3 \mathrm{ft}$ has veinlets of fine-grained $(<5 \mu \mathrm{m})$ polygonal polycrystalline quartz throughout the groundmass (Fig. 1a). In the stronger sample at 2944.6 to 2945.0 tt, veinlets of the same scale contain fewer and coarser quartz grains that are interyrown with spherulitic structures in the grounamass (Fig. 1b). The tightiy interlocked structure of the second sample is apparently stronger than the rounded grain tacings of the first sample. Petrographic observations can potentially explain property ditterences, such as these, that vary by $100 \%$ or more. The results of our examinations of the test samples, nowever, suggest that petrologic changes leading to 30 to $70 \%$ alfterences in sample strength may not require fabric modifications that can be observed petrographically.

A. Methods

Seven samples showing significant changes in mechanical properties were studied by optical petrographic, x-ray diffraction, electron microbeam, or 

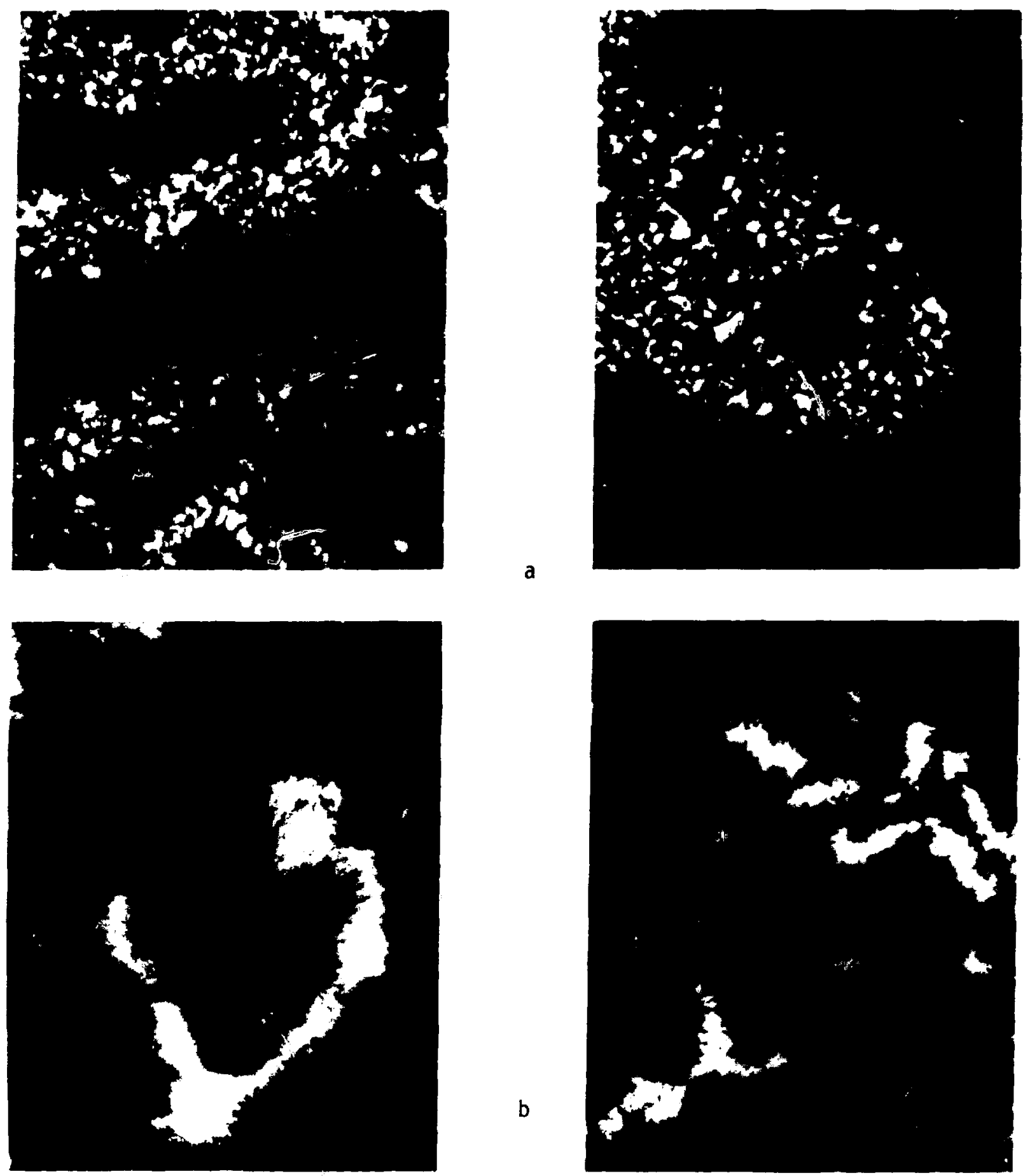

Fig. 1.

A comparison of the fine-grained polygonal texture of groundmass quartz in the Tram unit at $2773-\mathrm{ft}$ depth (a) and coarse intergrowths of groundmass quartz in the Tram unit at 2945-ft depth (b). All photographs are 1 by $1.5 \mathrm{~mm}$, taken with crossed polarizers. Note in particular the strengthening intergrowth of fine-grained acicular groundmass crystals within coarse single quartz crystals at 2945-ft depth (b). Both pictures are of samples before testing. 
scanning electron microscopy methods. Seven before-test samples and eight of the after-test samples (total fifteen) were studied. X-ray diffraction studies were made by taking splits of six before- and six after-test samples and yrinding them to $\mathrm{s} b \mathrm{U}-100$ mesh (U.15 to $U .3 \mathrm{~mm})$. A portion of this powaer was then ground under acetone to $s 300$ mesh $(b 0 \mu \mathrm{m})$. The ground powder was analyzea on a Sienens $U$-buU powder diffractometer using a copper-target $x$-ray tube and a diffracted-beam monochromator. The diffractometer was run between $2^{\circ}$ and $32^{\circ} 2 \theta$ at a scanning rate of $2^{\circ} 2 \theta$ per munute. Examples of $x$-ray diffraction patterns are shown in Fig. 2 . Mineral identification was accomplisned by comparison of observed patterns to standaras from the Joint Committee on Powder Diffraction Standaras (JCPDS). Estimation of concentrations of the various minerals present was accomplished through coniparison to in-lab standard patterns of known mixtures. Further details of $x$-ray diftraction methods can be found in kefs. 3 and 4 . The results of $x$-ray diffraction analysis are summarized in Table 11 .

Electron microprobe analyses of clays and zeolites were made on an automated Cameca model MBX electron microprobe with accelerating potential fixed at $15 \mathrm{keV}$ and sample current at $4.01 \mathrm{~b} \mu \mathrm{A}$ on thorium oxide. Analyses were made for either $10 \mathrm{~s}$ or 30 ' $'$ Jo counts for each element. In the Appendix, data are listed in Table A-l for before-test and after-test zeolites in the sample from the Calico Hills unit and in Table A-Il for after-test clays in the sample from the Bullfrog Member.

lmaging and qualitative composition studies were made on an ISI model DS-130 scanning electron microscope, operated at variable keV (up to $40 \mathrm{keV}$ ). Semiquantitative and qualitative analyses from primary $x$-ray signals were obtained on a Kevex model 7000 energy-dispersive system with the electron beam operating at ib kev. Back-scattered and secondary-electron images are described in this report.

b. Results of Petrologic and Mineralogic Studies

1. Topopah Spring Member of the Paintbrush Tuff. Samples from 1089.7 to $1090.3 \mathrm{ft}$, from 1100.6 to $1101.6 \mathrm{ft}$, and from 1105.8 to $1106.8 \mathrm{ft}$ tested at $120^{\circ} \mathrm{C}$ ( 5.5 months), $180^{\circ} \mathrm{C}\left(3.5\right.$ months), ana $80^{\circ} \mathrm{C}$ (6 months) (tests $\# 3$, \#7, and \#1, Table 1 , respectively).

These three samples from the Topopan Spring unit are all from arill nole UE-2ba\#1 within the 997- to 1199-ft densely welded devitrified subunt as described for USW b-l by Spengler et al. " All samples are phenocryst poor 
a
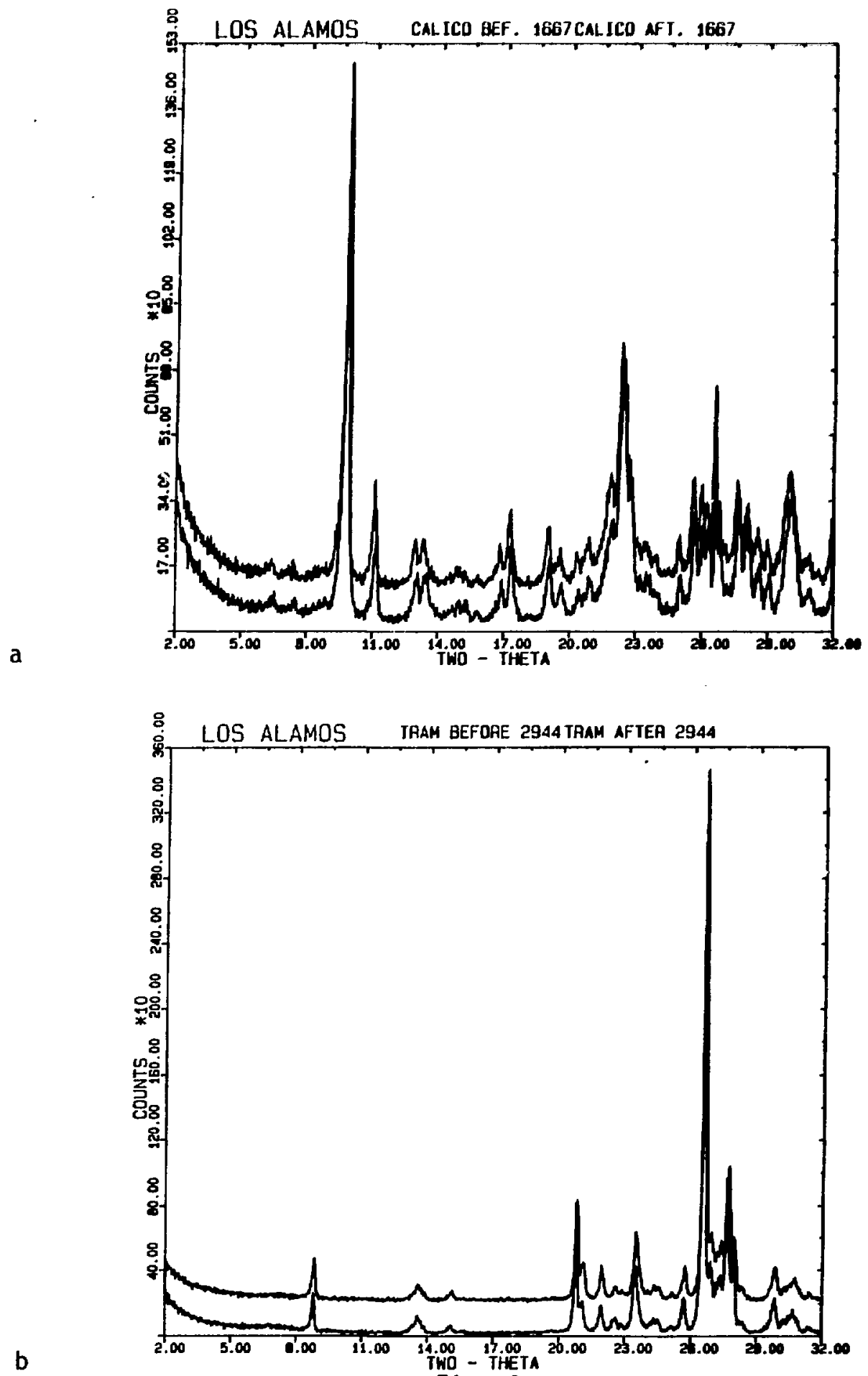

Fig. 2 .

(a) X-ray diffraction patterns of Calico Unit (1667-ft depth) before (Jower pattern) and after (upper pattern) treatment at $120^{\circ} \mathrm{C}$ for 2.5 months. (b) Tram unit (2944-ft depth) before (lower pattern) and after (upper pattern) treatment at $180^{\circ} \mathrm{C}$ for 3.5 months. 


\section{RESULTS OF X-RAY DIFFRACTION STUDIES OF SOAK TEST SAMPLES}

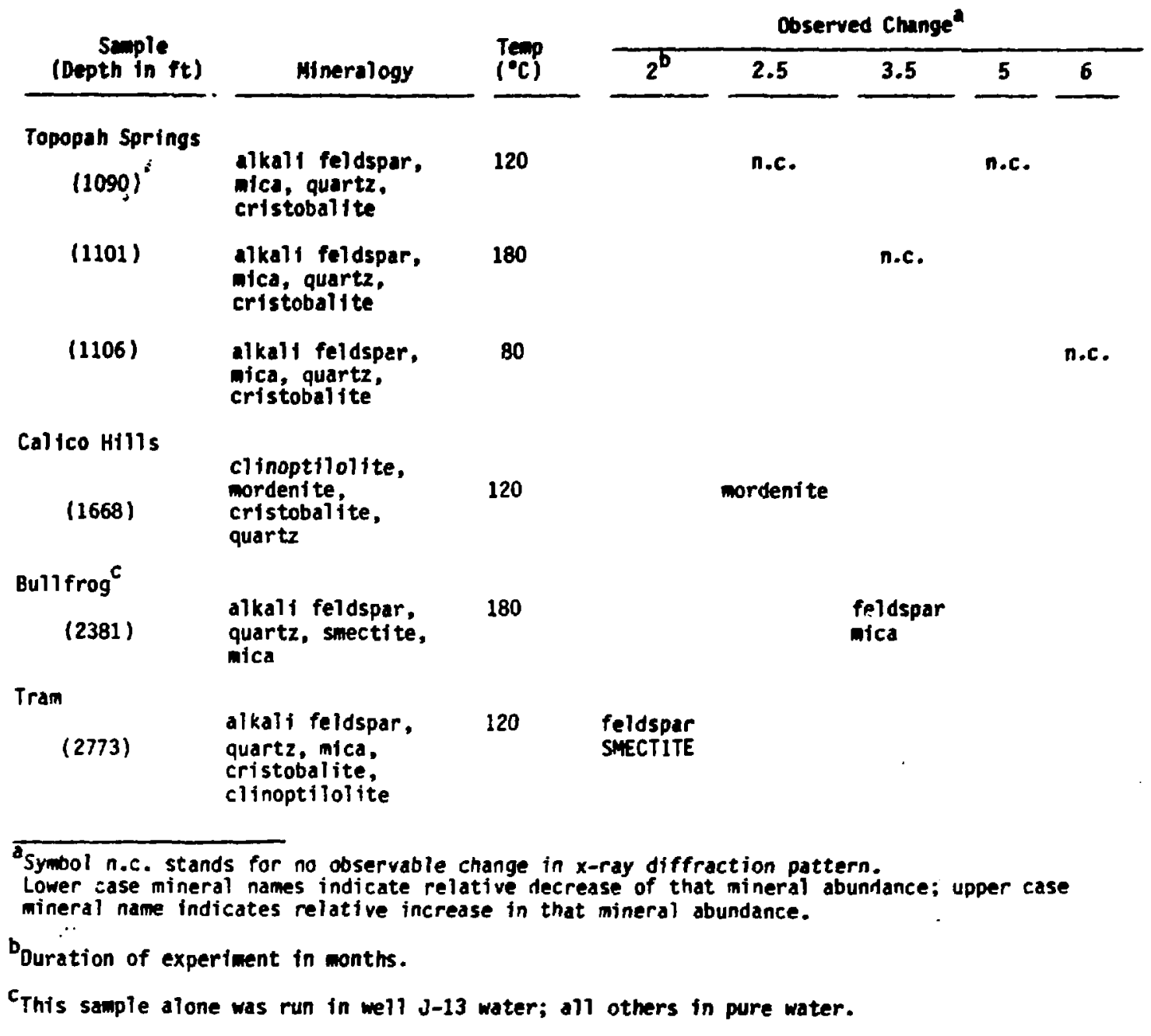

( $1 \%$ ) with plagioclase dominant. Listed in order of decreasing relative abundance, the phenocrysts in the 1089.7- to 1090.3-ft sample are plagioclase-sanidine-biotite, those in the 1100.6- to 1101.6-ft sample are plagioclase-sanidine-quartz, and those in the 1105.8- to 1106.8-ft sample are plagioclase-quartz-sanidine-magnetite. The small amount of phenocrysts in all of these samples and the lack of any notable changes in phenocryst composition, morphology, or Fe-Ti oxides suggest that any modifications of the phenocrysts in these tests have trivial effects on mechanical properties.

The groundmass textures in all three samples are largely the product of dense welding followed by devitrification. Pumices are flattened and well 
foliated, and the groundmass is dominated by subequant granular intergrowtins of quartz (and/or cristobalite) and feldspar with minor clay, all comonly with grain sizes $<5 \mu \mathrm{m}$. Veinlets of granular quartz are common throughout all three samples.

$X$-ray diffraction studies indicate no discernible differences between any of the three before-test and after-test paired samples from the Topopah Spring unit. Petrographic study reveals no visible differences in grain population or morphology, and this conclusion is reinforced by the comparable lack of any notable changes as a result of scanning electron microscope studies. The only possible mineralogical modification noted by optical microscope studies occurs in the sample at 1105.8 to $1106.8 \mathrm{ft}$, which was held at the lowest temperature $\left(80^{\circ} \mathrm{C}\right)$ for the longest time (6 months). Pumices in this after-test sample appear to have lost some silica, probably by dissolution. Dissolution of quartz may correlate with the observed slight porosity increase (11\%).

The other two samples analyzed from the Topopah Spring Menber had significant increase in compressive strength $(69 \%)$ at $120^{\circ} \mathrm{C}$ for 5.5 months (1089.7 to $1090.3 \mathrm{ft}$ ) and decreases in both compressive strength (14\%) and tensile strength $(46 \%)$ after 3.5 months at $180^{\circ} \mathrm{C}(1100.6$ to $1101.6 \mathrm{ft})$. These opposed differences cannot be correlated with any ubservable change in mineral type, form, abundance, or fabric. Highly variable results such as this suggest either that grain-boundary transformations are taking place on a very fine scale, possibly due to variations in solution and redeposition of silica at various temperatures, or that the results are complicated by sample heterogeneity. Heterogeneity in mechanical properties may be an important aspect of the Topcpah Spring samples, where lithophysae may form $15 \%$ or more of the rock. ${ }^{2}$ The samples chosen for test $y$ were selected to avoid lithophysae, but it is difficult to recognize the diffuse textural boundaries of the larger lithophysae and it is not always possible to avoid smaller and more widely dispersed lithophysae-like vapor crystallization features. Small pockets of vapor-phase crystallization can be seen in some of the pumices from the sample at 1105.8 to $1106.8 \mathrm{ft}$.

2. Tuff of Calico Hills. Sample from 1667.3 to $1668.4 \mathrm{ft}$ tested at $120^{\circ} \mathrm{C}$ (2.5 months) and $180^{\circ} \mathrm{C}$ (3.5 months) (tests $\# 5$ and $\# 7$, respectively, Table I).

Samples from the zeolitized tuff of Calico Hills show a significant increase in tensile strength $(22 \%)$ and slight porosity and grain-density 
increases (5 to $19 \%$ ) when held at $120^{\circ} \mathrm{C}$ for 2.5 months. There were only slight changes at $180^{\circ} \mathrm{C}$ (statistically insignificant). These samples were analyzed petrographically and by x-ray diffraction because the Calico Hills unit is highly zeolitized in holes UE-25a\#1 and USW G-1, and the sorptive properties of zeolites are important to any potential repository at rucca Mountain. The part of the Calico Hills unit tested consists largely of nonwelded phenocryst-poor ash-flow tuff and thin incervening bedded/reworked zones. ${ }^{2}$ The nonwelded ash flows contain abundant small pumice fragments $(0.5$ to $1 \mathrm{~cm}$ ) and rare large pumices $(\backsim 3 \mathrm{~cm})$. The samples tested contain less than $2 \%$ phenocrysts, which are, in decreasing order of abundance, plagioclasequartz-sanidine-biotite. The groundmass texture of the ash-flow tuffs in the Calico Hills is dominated by interlocking zeolite, silica and K-feldspar growth, commonly to the exclusion of clay. ${ }^{3}$ Poorly connected cavities in pumice fragments may be lined by euhedral clinoptilolite and K-feldspar or (less commonly) by both clinoptilolite and opal.

We have attempted to determine whether the clinoptilolite crystals are destabilized by hydrothermal exposure at temperatures of 120 and $180^{\circ} \mathrm{C}$, and whether these zeolites undergo any significant change in cation composition at those temperatures. The Calico Hills samples studied also contain abundant mordenite which occurs as small fibrous crystals less than $1 \mathrm{\mu m}$ in diameter. Such small crystals cannot be analyzed by electron microprobe for evidence of change in cation composition. Electron microprobe studies indicate that no significant compositional change has occurred in the clinoptilolites subjected to temperatures of 120 or $180^{\circ} \mathrm{C}$. Table A-I 1 ists 12 before-test zeolite analyses, 25 after-test zeolite analyses for $120^{\circ} \mathrm{C} / 2.5$-month conditions (16 analyses from the center of the after-test sample and 9 analyses from the exposed sample rim), and 13 after-test zeolite analyses for $180^{\circ} \mathrm{C} / 3.5-m o n t h$ conditions. The test results are summarized in Table III and in Fig. 3. Table III shows the mean $\mathrm{SiO}_{2}, \mathrm{Al}_{2} \mathrm{O}_{3}, \mathrm{CaO}, \mathrm{Na}_{2} \mathrm{O}$ and $\mathrm{K}_{2} \mathrm{O}$ values (as well as the mean normalized Ca-Na-K cation composition) for all before-test and after-test conditions, as well as the (10) standard deviation for each listing. Figure 3 compares the before-test normalized $\mathrm{Ca}-\mathrm{Na}-\mathrm{K}$ compositions of zeolites with compositions after the tests. The before-test sample (Fig. 3a) includes the average composition (small open circle) as well as the $2 \sigma$ area (circled) within which $98 \%$ of the analyses within this particular sample are expected to fall. The means of all after-test analyses fall well within the 20 circle for 


\section{COMPARISONS OF AVERAGE CALICO CLINOPTILOLITE COMPOSITIONS BEFORE AND AFTER TESTING}

\begin{tabular}{|c|c|c|c|c|}
\hline & $\begin{array}{l}\text { Calico } \\
\text { Before }\end{array}$ & $\begin{array}{r}\text { After Te } \\
\text { Calico at } \\
\text { Center }\end{array}$ & ${\stackrel{\text { Rim }}{\mathrm{C}^{\mathrm{a}}}}^{\mathrm{a}}$ & Calico at $180^{\circ} c^{a}$ \\
\hline $\mathrm{SiO}_{2}$ & $65.0 \pm 2.7$ & $67.3 \pm 1.9$ & $67.1 \pm 2.1$ & $65.2 \pm 2.9$ \\
\hline $\mathrm{Al}_{2} \mathrm{O}_{3}$ & $11.6 \pm 0.5$ & $11.8 \pm 0.5$ & $11.8 \pm 0.4$ & $11.8 \pm 0.7$ \\
\hline $\mathrm{CaO}$ & $3.58 \pm 0.19$ & $3.79 \pm 0.36$ & $3.60 \pm 0.25$ & $3.65 \pm 0.34$ \\
\hline $\mathrm{Na}_{2} \mathrm{O}$ & $0.77 \pm 0.15$ & $0.68 \pm 0.22$ & $0.88 \pm 0.15$ & $0.79 \pm 0.23$ \\
\hline $\mathrm{K}_{2} \mathrm{O}$ & $2.55 \pm 0.42$ & $2.31 \pm 0.39$ & $2.20 \pm 0.30$ & $2.40 \pm 0.40$ \\
\hline $\mathrm{Ca}$ & $44 \pm 4$ & $49 \pm 7$ & $46 \pm 4$ & $46 \pm 4$ \\
\hline $\mathrm{Na}$ & $17 \pm 3$ & $16 \pm 4$ & $20 \pm 2$ & $18 \pm 4$ \\
\hline$k$ & $38 \pm 4$ & $35 \pm 4$ & $33 \pm 3$ & $36 \pm 2$ \\
\hline
\end{tabular}

all data, both "before" and "after" test, are from zeolitized samples from the 1667.3 - 1668.4-ft depth of drill core UE-25a\#1.

the before-test sample (Fig. 3b, C). Although individual data points in some of the after-test samples fall outside of the before-test $2 \sigma$ area, we interpret those variations as sample-to-sample heterogeneity rather than test-induced cation exchange. We base this interpretation on the fact that there is no systematic shift between the compositions of zeolites exposed at $120^{\circ} \mathrm{C}$ and those exposed at $180^{\circ} \mathrm{C}$ and on the assumption that, al though the zeolites in all samples fali near a common compositional range, they are not nocessarily at equilibrium. There are large local variations in minor element cr: Itent (particularly barium, see Table A-I) of clinoptilolite in the tuff of Calico Hills. The average after-test zeolite compositions are all slightly more calcium-rich than the average befire-test zeolite composition, but it is not known whether this shift may become significant if the test conditions were prolonged.

3. Bullfrog Member of the Crater Flat Tuff. Sample from 2380.6 to $2381.2 \mathrm{ft}$ tested at $180^{\circ} \mathrm{C}$ (3.5 months) (test \#8, Table I).

This sample had significant increases in tensile strength (14\%) and compressive strength (31\%) after testing. The sample is of slightly welded tuff with some vapor-phase crystallization. Phenocrysts are abundant (12\%) and include plagioclase-sanidine-quartz-biotite-magnetite in order of decreasing abundance. Pumices are generally less than $1 \mathrm{~cm}$ long and poorly flattened, and scattered silicic volcanic fragments are $0.5 \mathrm{~cm}$ in diameter. 

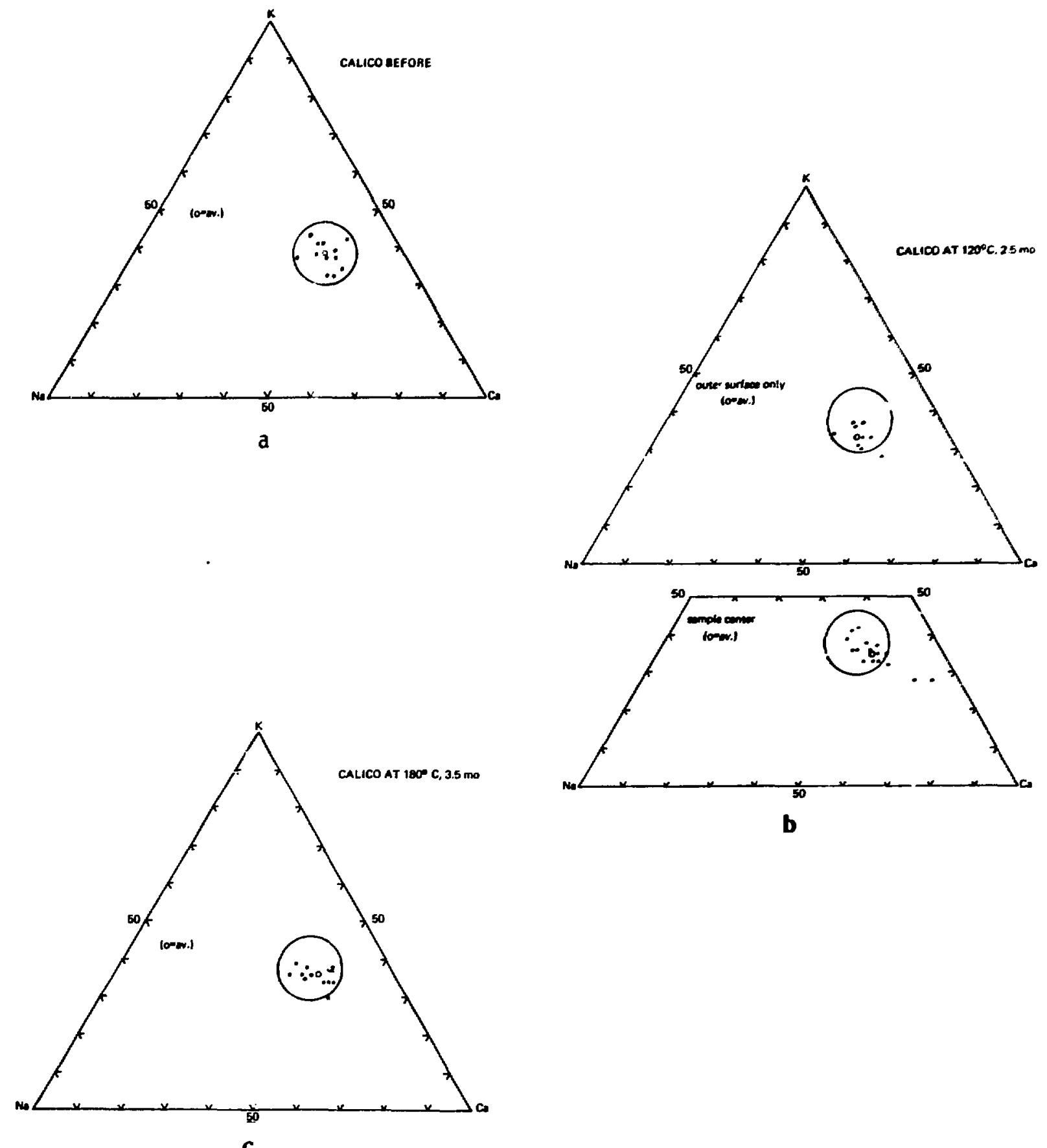

b

Fig. 3.

Clinoptilolite compositions in the Calico Unit before testing (a), along the exposed outer surface and with a core tested at $120^{\circ} \mathrm{C}$ for 2.5 months (b), and from a core tested at $180^{\circ} \mathrm{i}$ for 3.5 months (c). The average clinoptilolite composition for each figure is shown as a small open circle. In none of the tests do the average compositions fall outside the large open circle that represents the $2 \sigma$ area of expected variation in clinoptilolite compositions before testing. 
The before-test sample contains dark opaque veins of amorphous manganese oxides or hydrates with small amounts of $\mathrm{BaO}$ ( $3 \%$ weight) and $\mathrm{FeO}$ ( $3 \%$ weight). These manganese-rich vein fillings are not found in the after-test samples. Groundmass textures are dominated by quartz and feldspar intergrowths with abundant, very fine-grained birefringent clay.

$x$-ray diffraction analysis indicates no significant change in mineral type or abundance between the before-test and after-test samples. Petrographic observation, however, shows that the manganese-rich veins are not present in the after-test samples and the clays appear to be coarser in the after-test samples. Clay crystals in the before-tesi samples are far too fine-grained $\left(<2 \mu_{m}\right)$ to analyze by electron microprobe, but the clay crystals in the after-test sample are as much as 20 to $30 \mathrm{\mu m}$ long and are large enough to analyze (Table A-II). These clays are $\mathrm{Na-Ca-saturated} \mathrm{expardable}$ smectites. The coarsening of clay crystals at $180^{\circ} \mathrm{C}$ with intergrowth arcund groundmass quartz and feldspar may account for the increased strength of the after-test samples. Clay growth may also account for the slight porosity decrease in the after-test sample.

4. Tram Member of the Crater Flat Tuff. Samples from 2772.7 to 2773.3 $\mathrm{ft}$ and from 2944.6 to $2945.0 \mathrm{ft}$ tested at $120^{\circ} \mathrm{C}$ (2 months) and $180^{\circ} \mathrm{C}(3.5$ months) (tests \#10 and \#8, Table I) respectively.

These samples are both from a single subunit of the Tram Member in hole USW G-1, which extends from 2639 to $3083 \mathrm{ft}^{2}$. This subunit is partially welded and devitrified to a groundmass of quartz, feldspar, and clay intergrowths with small (5 mm) veins of quartz. These veins of quartz were described above (Fig. la,b) to explain the great variability in strength within the Tram unit: coarsely crystalline quartz veins interlock with adjacent spherulitic structures, whereas fine-grained polygonal quartz without crystal intergrowths provides a weaker matrix. These samples are otherwise similar in composition, and rare zeolites $(<3 \%)$ occur in voids in both samples. Both the sample from 2772.7 to $2773.3 \mathrm{ft}$ and the sample from 2944.6 to $2945.0 \mathrm{ft}$ are phenocryst rich (10 to $13 \%$ phenocrysts) and both have plagioclase-sanidine-biotite phenocrysts (in decreasing order of abundance), although the sample from 2944.6 to $2945.0 \mathrm{ft}$ has about $2 \%$ quartz phenocrysts as well. Pumice fragments and fragments of siliceous volcanic rocks, slightly less than $1 \mathrm{~cm}$ in diameter, are common to both samples. The most notable 
difference between samples is the differing grain size within their small quartz veins, a feature that was not affected by the test procedures.

Scanning electron microscope images indicate that the clinoptilolite grains projecting into vugs may undergo some surface modification at $120^{\circ} \mathrm{C}$. The well-develcped euhedral clinoptilolite forms that occur in the before-test samples (Fig. 4a) are degraded in the after-test samples at $120^{\circ} \mathrm{C}$ (Fig. $4 \mathrm{~b}$ ). Moreover, mordenite fibers seem to be coarser and better formed in the aftertest samples $\left(120\right.$ and $\left.180^{\circ} \mathrm{C}\right)$ than in the before-test samples. X-ray diffraction studies, however, suggest no significant decrease in clinoptilolite abundance and no significant increase in mordenite abundance (Table I). This conclusion is corroborated by petrographic observations that show no decrease in the abundance of clinoptilolite crystals, even though their exterior surfaces may be slightly modified. The growth of mordenite in cavities under hydrothermal conditions does seem to be well documented by the scanning electron microscope analysis, but the quantities formed are so small ( $<1 \%)$ that no changes other than those attributable to sample heterogeneity can be seen in the x-ray diffraction analysis (Fig. 2b). Nevertheless, definite mineralogic changes are evident in the after-test samples, and such changes in zeolitized cuff held at these or even lower temperatures for many years may be very important to the repositury environment.

The Tram samples treated at $120^{\circ} \mathrm{C}$ for 2 months and at $180^{\circ} \mathrm{C}$ for 3.5 months both experienced a decrease in porosity of 8 to $9 \%$. The one sample held at $120^{\circ} \mathrm{C}$ for 2 months showed a significant decrease in tensile strength (30\%) and a marginally significant decrease in compressive strength (25\%). The sample held at $180^{\circ} \mathrm{C} / 3.5$ months showed no statistically significant change in strength. No petrographic evidence sas found to explain the decreased porosity. It is imporiant to note that $x$-ray diffraction study indicates a possibly significant decrease in feldspar content and an increase of smectite clay content in the after-test sample that was held for 2 months at a temperature of $120^{\circ} \mathrm{C}$. Petrographic examination shows a slight increase in intergranular clay, although it is very fine-grained and cannot be analyzed by electron microprobe. These changes may explain the reduction in strength.

C. Summary of Observations

Petrographic, electron microprobe, $x$-ray diffraction, and scanning electron microscope studies of samples from seven depth levels in UE-25a*1 and USW G-1 cores reveal only three mineralogic changes that may be correlated 


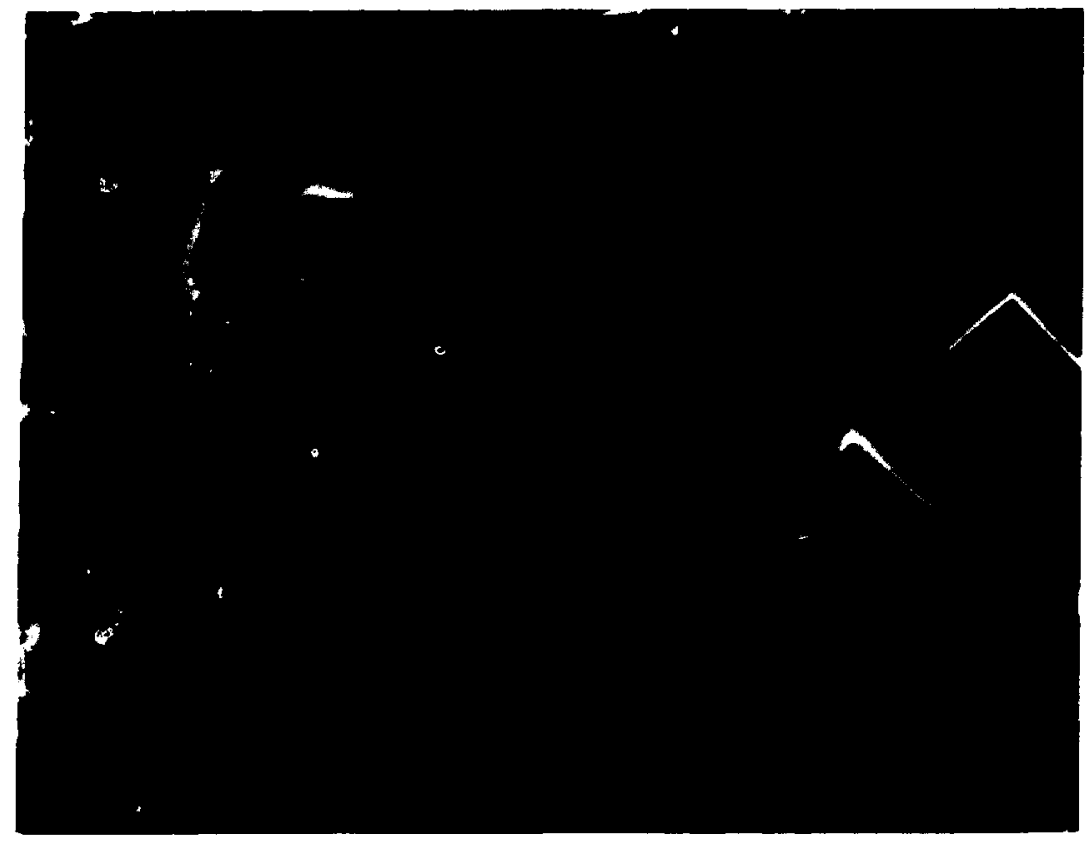

a

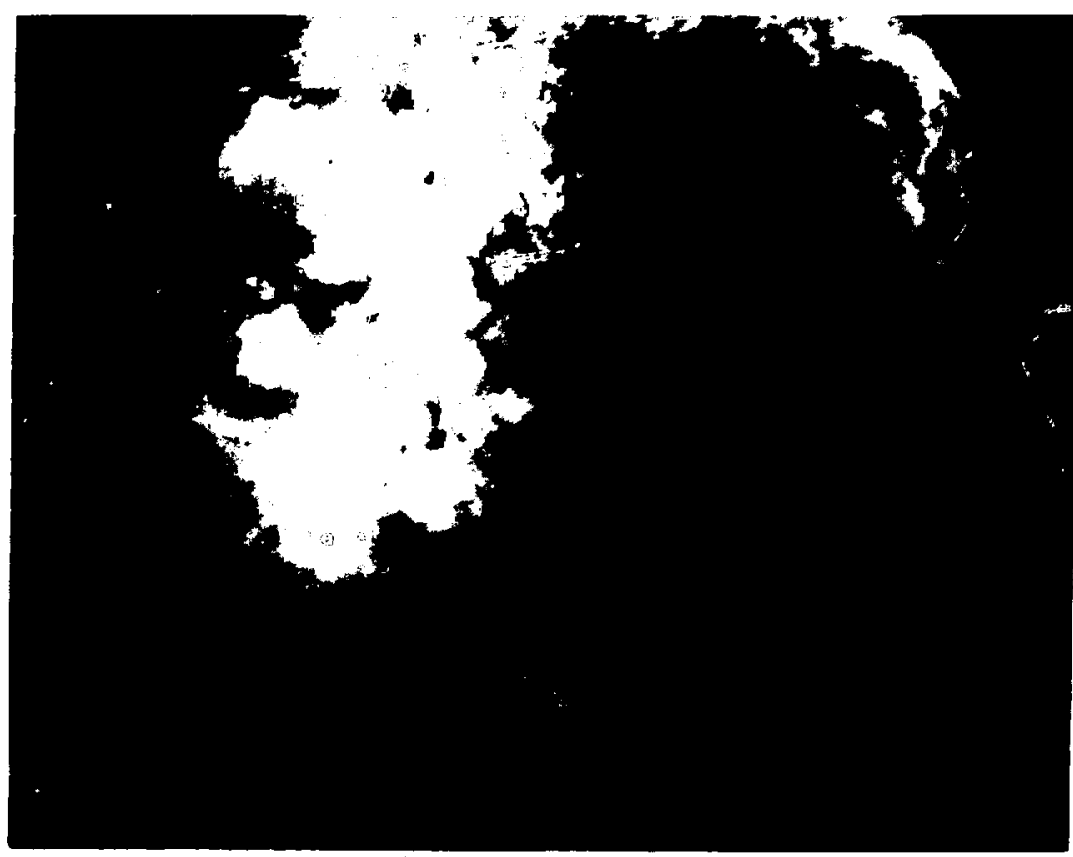

b

Fig. 4.

Euhedral clinoptilolite crystals in the Tram unit at 2772.7- to 2773.3-ft depth (a), contrasted with degraded clinoptilolite grains that occur in the sample after testing at $120^{\circ} \mathrm{C}$ for two months (b). Note that (b) was photographed at a scale 25\% larger than (a). 
with changes in mechanical properties due to elevated temperatures. All of these changes could occur in each of the units, but we have on 1; been able to demonstrate them in specific samples summarized below. One sample from the Topopah Spring unit exposed at $80^{\circ} \mathrm{C}$ for 6 months had an increase in porosity that may be correlated to dissolution of silica, and a sample from the Bullfrog unit exposed at $180^{\circ} \mathrm{C}$ for 3.5 months had significant increases in tensile and compressive strength that may be correlated with a coarsening of clay crystals. One sample from the Tram unit exposed at $120^{\circ} \mathrm{C}$ for 2 months had a loss of feldspar and an increase in fine-grained clay content that might correlate with a slight decrease in tensile strength.

Hydrothermal exposures at 120 and $180^{\circ} \mathrm{C}$ lead to a slignt degradation of surface inorphology in euhedral clinoptilolite crystals and suggest a recrystallization of fibrous mordenite crystals in void spaces. The loss or gain of either mordenite or clinoptilolite was not great enough to be observed in $x$-ray diffraction studies, but the morphological changes observed suggest that loss of clinoptilolite and increase in mordenite may be the consequence of more prolonged exposure. No significant cation exchange was observed in clinoptilolite at either $120^{\circ} \mathrm{C}$ or at $180^{\circ} \mathrm{C}$.

Changes in mechanical properties that do not correlate with observed petrologic and mineralogic changes may be due to small-scale grain-boundary changes or may simply reflect the complex heterogeneities in tuff. Pumice fragments, lithic fragments, fractures, and lithophysae are large discontinuous features that may introduce highly variable mechanical behavior in test samples that are limited to $2.5-\mathrm{cm}$ diameter. Petrographic observations to date are more useful in explaining major differences in mechanical properties between and within units, as in the explanation of variable strength within the Tram unit as due to the grain size and morphologies of quartz veinlet and groundmass intergrowths.

IV. INVESTIGATION OF POSSIBLE MATRIX PERMEABILITY ChaNGES

A. Introduction

The dominant means of migration of hazardous material associated with a high-level nuclear waste repository will be due to transport in groundwater. Therefore, it is very important to know the hydraulic properties of the host rock mass. Part of the flow will likely be along discontinuities such as fractures and joints, with a variable amount of transport through the porous 
matrix, espectally in the unsaturatec zone. It is conceivable that in the thermal and stress field of a repository, mineralogic changes such as dissolution and redeposition could alter the flow channels to such an extent as to grossly change the local hydraulic properties. Any such changes would develop slowly over time; therefore, we made a few preliminary matrix permeability measurements on selected samples before and after extended temperature and pressure exposure to evaluate this possibility.

B. Test Method

All tests were conducted at room temperature (about $20^{\circ} \mathrm{C}$ ) on saturated samples. Both permeability and storage capacity were determined at values of effective confining pressure (confining pressure minus pore pressure) between 0.5 and $30 \mathrm{MPa}$. Storage capacity is the additional volume of fluid that can be stored in a unit volume of rock by a unit increase in the pore fluid pressure. Connected porosity was also determined from the dry and wet weights of the samples. Because there was some doubt that all the pore volume was filled with water, average mineral densities were also calculated. They agree quite well with those expected from the mineralogies of the rocks.

A detailed discussion of the method is given in Appendix $F$ of the preliminary report. ${ }^{1}$ In brief, the method involves applying a pore pressure pulse across the sample and observing the exponential decay of the pressure difference as water flows into the sample. The permeability and storage capacity were calculated using the method presented by Hsieh et al. 5

C. Results

Tables IV and $V$ list the results for the two rock units tested.

1. Topopah Spring Member. Sample from $1087.3-1087.8 \mathrm{ft}$ tested at $120^{\circ} \mathrm{C}$, 19.7-MPa confining pressure, and $19.7-\mathrm{MPa}$ pore pressure $(2.5$ months) (test $\# 5$, Table I). Sample from $1100.6-1101.6 \mathrm{ft}$ tested at $120^{\circ} \mathrm{C}, 9.7-\mathrm{MPa}$ confining pressure, and 0.5-MPa pore pressure (5.5 months) (test \#4, Table I).

There is a large ( $22 \%$ ) increase in matrix permeability for both side-by-side samples after exposure. Whether these differences are a reflection of original sample inhomogeneity or result from the exposure conditions of the tests cannot be determined without further testing. There is also a significant difference in storage capacity of the before and after samples of 1100.6 to $1101.6 \mathrm{ft}$.

2. Calico Hills Unit. Sample from 1370.8 to $1371.4 \mathrm{ft}, 120^{\circ} \mathrm{C}, 9.7-\mathrm{MPa}$ confining pressure, $0.5-\mathrm{MPa}$ pore pressure $(5.5$ months) (test $\# 4$, Table I). 
TABLE IV

HYDRAULIC PROPERTIES OF TOPOPAH SPRING TUFF

A. Sample Number: 2087.3 to 2087.8 Before.

Length: $2.375 \mathrm{~cm}$

Yolume: $12.03 \mathrm{~cm}^{3}$

Wet weight: $28.568 \mathrm{~g}$ Dry weight: $27.221 \mathrm{~g}$

Porosity: 11.2\%

Average Mineral Density: $2.55 \mathrm{~g} / \mathrm{cm}^{3}$

Effective Confining

\begin{tabular}{|c|c|c|}
\hline $\begin{array}{l}\text { Pressure } \\
\text { (IPa) }\end{array}$ & $\begin{array}{l}\text { Permeability } \\
\left(m^{2}\right)\end{array}$ & $\begin{array}{c}\text { Storage Capacity } \\
\text { (1/MPal }\end{array}$ \\
\hline $\begin{array}{r}1.45 \\
2.09 \\
2.72 \\
3.44 \\
4.14 \\
4.95 \\
5.66 \\
6.37 \\
7.07 \\
8.47 \\
8.54 \\
9.77 \\
13.19\end{array}$ & $\begin{array}{l}1.37 \mathrm{E}-19 \\
1.34 \mathrm{E}-19 \\
1.60 \mathrm{E}-19 \\
1.71 \mathrm{E}-19 \\
1.55 \mathrm{E}-19 \\
1.56 \mathrm{E}-19 \\
1.66 \mathrm{E}-19 \\
1.59 \mathrm{E}-19 \\
1.61 \mathrm{E}-19 \\
1.42 \mathrm{E}-19 \\
1.45 \mathrm{E}-19 \\
1.45 \mathrm{E}-19 \\
1.33 \mathrm{E}-19\end{array}$ & $\begin{array}{l}4.1 E-04 \\
3.2 E-04 \\
2.0 E-04 \\
1.6 E-04 \\
1.6 E-04 \\
1.4 E-04 \\
1.2 E-04 \\
1.2 E-04 \\
1.1 E-04 \\
1.0 E-04 \\
1.1 E-04 \\
1.1 E-04 \\
1.0 F-04\end{array}$ \\
\hline
\end{tabular}

B. Sample Number: 2087.3 to 1087.8 After.

Length: $2.662 \mathrm{~cm}$

Yolume: $13.49 \mathrm{~cm}^{3}$

Wet Weight: $31.458 \mathrm{~g}$ Dry Weight: $29.586 \mathrm{~g}$

Porosity: $13.8 \%$

Average Mineral Density: $2.54 \mathrm{~g} / \mathrm{cm}^{3}$

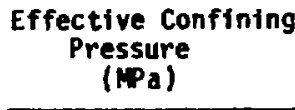

1.26

1.83

2.45

3.07

3.71

4.36

4.98

5.56

6.21

6.80

7.46

8.82

12.20

15.59

19.03

22.49

25.93

29.25
Permeability Storage Capacity (m2) (1/MPa)

5.23E-19

5.20E-19

5.37E-19

5.53E-19

5.90E-19

6.52E-19

4.99E-19

5.70E-19

6.25E-19

6.30E-19

6.15E-13

6.06E-19

5.97E-19

6.92E-19

$6.12 E-19$

$6.73 E-19$

6.76E-19

7.11E-19
2.8E-04

2.0E-04

1.6E-04

1.5E-04

1.3E-04

1.2E-04

1.4E-04

1.2E-04

1.1E-04

1.1E-04

1.1E-04

1.1E-04

1.1E-04

1. OE-04

1. OE-O4

1.0E-0.

9.3E-05

9.5E-05 


\section{TABLE IV (cont)}

C. Sample Number 1100.6 to 1101.6 Before.

Length: $2.388 \mathrm{~cm}$

Volume: $12.10 \mathrm{~cm}^{3}$

Wet Weight: $28.909 \mathrm{~g}$ Dry Weight: $27.701 \mathrm{~g}$

Porosity: 10.08

Average Mineral Density: $2.54 \mathrm{~g} / \mathrm{cm}^{3}$

Effective Cunfining

Pressure

(MPa)

$\begin{array}{cc}\begin{array}{c}\text { Permeabflity } \\ \left(\mathrm{m}^{2}\right)\end{array} & \text { Storage Capacity } \\ (1 / \mathrm{MPa})\end{array}$

0.50

$6.45 E-19$

$3.6 \mathrm{E}-04$

1.02

$4.74 E-19$

3.1E-04

2.48

3.36E-19

2.4E-04

3.13E-19

1. BE-04

3.20

3.89

2.98E-19

$1.6 \mathrm{E}-04$

4.46

5.16

$2.90 \mathrm{E}-19$

1. AE-04

2.89E-19

1.4E-04

2.75E-19

$1.4 E-04$

5.92

$2.59 \mathrm{E}-19$

$1.4 E-04$

6.55

7.23

2.53E-19

1. $4 E-04$

2.55E-19

1. $4 E-04$

8.64

2.36E-19

$1.4 \mathrm{E}-04$

11.99

15.27

2.21E-19

$1.4 E-04$

1.97E-19

1.5E-04

D. Sample Number: 1100.6 to 1101.6 After.

Length: $3.091 \mathrm{~cm}$

Yolume: $15.66 \mathrm{~cm}^{3}$

Wet Weight: $37.960 \mathrm{~g}$ Dry Weight: $36.739 \mathrm{~g}$

Porosity: $7.7 \%$

Average Mineral Density: $2.54 \mathrm{~g} / \mathrm{cm}^{3}$

Effective Confining

\begin{tabular}{|c|c|c|}
\hline $\begin{array}{l}\text { Pressure } \\
\text { (MPa) }\end{array}$ & $\begin{array}{l}\text { Permeabi]ity } \\
\qquad\left(\mathrm{m}^{2}\right)\end{array}$ & $\begin{array}{c}\text { Storage Capacity } \\
(1 / \mathrm{MPa})\end{array}$ \\
\hline $\begin{array}{r}0.38 \\
0.76 \\
1.39 \\
2.08 \\
2.67 \\
3.28 \\
3.99 \\
4.54 \\
5.21 \\
6.00 \\
6.85 \\
7.67 \\
9.23 \\
16.19 \\
22.23 \\
25.43 \\
28.23\end{array}$ & $\begin{array}{l}2.37 E-18 \\
1.36 E-18 \\
9.16 E-19 \\
7.07 E-19 \\
6.50 E-19 \\
6.13 E-19 \\
5.86 E-19 \\
5.57 E-19 \\
5.71 E-19 \\
5.32 E-19 \\
4.93 E-19 \\
4.87 E-19 \\
4.60 E-19 \\
3.73 E-19 \\
3.64 E-19 \\
3.53 E-19 \\
3.34 E-19\end{array}$ & $\begin{array}{l}1.5 E-04 \\
2.1 E-04 \\
1.7 E-04 \\
1.2 E-04 \\
9.9 E-05 \\
8.7 E-05 \\
8.0 E-05 \\
7.9 E-05 \\
7.3 E-05 \\
7.2 E-05 \\
7.1 E-05 \\
6.7 E-05 \\
6.4 E-05 \\
5.6 E-05 \\
5.8 E-05 \\
5.8 E-05 \\
5.8 E-05\end{array}$ \\
\hline
\end{tabular}


HYDRAUL IC PROPERTIES OF CALICO HILLS TUFF

A. Sample Number: 1370.8 to 1371.4 Before.

Sength: $2.306 \mathrm{~cm}$

Volume: $11.69 \mathrm{~cm}^{3}$

Wet Weight: $22.422 \mathrm{~g}$ Dry Weight: $19.931 \mathrm{~g}$

Porosity: 21.3\%

Average Mineral Density: $2.17 \mathrm{~g} / \mathrm{cm}^{3}$

Effective Confining

Pressure

(MPO)

0.51

0.97

1.53

2.06

2.69

3.32

3.94

4.53

5.18

5.87

6.60

8.03

11.47

14.94

18.37

21.57

25.12

28.02

Permeability Storage Capacity
$\left(\mathrm{m}^{2}\right)$

5.29E-19

5.93E-19

6.93E-19

B.74E-19

9.63E-19

8.83E-19

9.84E-19

9.68E-19

9.44E-19

8.88E-19

9.03E-19

8.40E-19

$8.95 E-19$

8.91E-19

9.34E-19

1.03E-18

$9.00 \mathrm{E}-19$

$\therefore$.58E-19

B. Sample Number: 1370.8 to 1371.4 After.

B. Sample Number: 1370.8 to 1371.4 After.

Length: $3.137 \mathrm{~cm}$

Yolume: $15.90 \mathrm{~cm}^{3}$

Het Weight: $30.807 \mathrm{~g}$ Dry Weight: $26.751 \mathrm{~g}$

Porosity: $25.5 \%$

Average Mineral Density: $2.26 \mathrm{~g} / \mathrm{cm}^{3}$

Effective Confining

\begin{tabular}{|c|c|c|}
\hline $\begin{array}{l}\text { Pressure } \\
\text { (MPa) }\end{array}$ & $\begin{array}{c}\text { Perneability } \\
\qquad\left(m^{\prime} 2\right)\end{array}$ & $\begin{array}{c}\text { Storage Capacity } \\
(1 / \mathrm{MPa})\end{array}$ \\
\hline $\begin{array}{r}0.78 \\
1.29 \\
1.89 \\
2.46 \\
3.09 \\
3.81 \\
4.45 \\
5.18 \\
5.83 \\
6.49 \\
7.04 \\
8.37 \\
11.55 \\
14.41 \\
18.11 \\
21.63 \\
24.95 \\
28.25\end{array}$ & $\begin{array}{l}7.04 E-19 \\
7.07 E-19 \\
1.03 E-19 \\
1.14 E-18 \\
1.03 E-18 \\
9.57 E-19 \\
1.09 E-18 \\
9.15 E-19 \\
9.59 E-19 \\
9.79 E-19 \\
8.34 E-19 \\
9.11 E-19 \\
9.02 E-19 \\
9.70 E-19 \\
8.96 E-19 \\
8.39 E-19 \\
8.34 E-19 \\
8.28 E-19\end{array}$ & $\begin{array}{l}6.7 E-04 \\
5.6 E-04 \\
3.5 E-04 \\
3.2 E-04 \\
3.3 E-04 \\
3.4 E-04 \\
3.2 E-04 \\
3.4 E-04 \\
3.2 E-04 \\
3.1 E-04 \\
3.5 E-04 \\
3.1 E-04 \\
2.9 E-04 \\
2.8 E-04 \\
2.8 E-04 \\
2.8 E-04 \\
2.8 E-04 \\
2.8 E-04\end{array}$ \\
\hline
\end{tabular}


C. Sample Number: 1370.8 to 1371.4 After.

Length: $3.137 \mathrm{~cm}$

Volume: $15.90 \mathrm{~cm}^{3}$

Wet Weight: $30.807 \mathrm{~g}$ Dry Weight: $26.751 \mathrm{~g}$

Porosity: 25.54

Average Mineral Density: $2.26 \mathrm{~g} / \mathrm{cm}^{3}$

Effective Confining

Pressure
(MPa)

$\underset{\left(m^{2}\right)}{\stackrel{P}{P e r m e a b l i t y}}$ Storage Capacity

\subsection{4}

8.03

8.57

9.17

10.49

13.60

16.69

19.92

23.06

26.14

28.49

\begin{tabular}{l}
\hline 1.03E-18 \\
$9.65 E-19$ \\
$8.89 E-19$ \\
$9.92 E-19$ \\
$9.68 E-19$ \\
$9.60 E-19$ \\
$9.02 E-19$ \\
$9.56 E-19$ \\
$9.31 E-19$ \\
$8.53 E-19$ \\
$8.10 E-19$
\end{tabular}

2.9E-04

3.0E-04

3.3E-0.

2.9E-04

2.8E-04

$2.75-04$

2.9E-04

2.7E-04

2.7E-04

2.9E-04

3.0E-04

D. Sample Number: 1640.9 to 1642.1 Before.

Length: $2.337 \mathrm{~cm}$

Volume: $11.84 \mathrm{~cm}^{3}$

Wet Weight: $22.434 \mathrm{~g}$ Dry Weight: $19.000 \mathrm{~g}$

Porosity: $29.0 \%$

Average Mine-al Density: $2.26 \mathrm{~g} / \mathrm{cm}^{3}$

Effective Confining Pressure $\underset{\left(m^{2}\right)}{\operatorname{Permeability}} \begin{gathered}\text { Storage Capacity } \\ (1 / \mathrm{MPa})\end{gathered}$

(ina)

( $\mathbf{P P a}$

\subsection{7}

1.41

1.97

2.64

3.37

4.13

4.89

5.61

6.30

7.00

7.75

9.17

12.50

15.84

19.22

22.57

25.83

28.51

$\frac{\left(m^{2}\right)}{-}$

1.34E-18

1. $39 \mathrm{E}-18$

$1.45 \mathrm{E}-18$

$1.42 E-18$

1.37E-18

1.37E-18

1.32E-18

1.39E-18

1. $42 \mathrm{E}-18$

1. $46 \mathrm{E}-18$

1. $37 \mathrm{E}-18$

1. $42 \mathrm{E}-18$

1.33E-18

$1.47 E-18$

1.54E-18

$1.61 \mathrm{E}-18$

$1.72 \mathrm{E}-18$

1.43E-18
7.2E-04

6.4E-04

5.6E-04

5.3E-04

5.2E-04

4.8E-04

4.5E-04

4.2E-04

4.0E-04

3.9E-04

4.1E-04

3.7E-OA

3.6E-04

3.5E-0.4

3.2E-OA

3. 2E-04

3.1E-04

3.3E-04 
TABLE $V($ cont $)$

E. Sample Number: 1640.9 to 1642.1 After.

Length: $3.101 \mathrm{~cm}$

Yolume: $15.72 \mathrm{~cm}^{3}$

Wet Weight: $29.523 \mathrm{~g}$ Dry theight: $24.984 \mathrm{~g}$

Porcsity: 28.98

Average Mineral Density: $2.24 \mathrm{~g} / \mathrm{cm}^{3}$

Effective Confining

Pressure
(Ma)

Permeability Storage Capacity

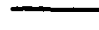

1.38

2.46

3.61

4.12

4.65

5.31

5.91

7.24

7.88

10.13

13.41

16.70

20.06

23.43

26.77

29.81

\begin{tabular}{|c|c|}
\hline$\left(m^{2}\right)$ & (1//PPa) \\
\hline $\begin{array}{l}1.98 E-18 \\
1.95 E-18 \\
1.93 E-18 \\
1.98 E-18 \\
2.07 E-18 \\
1.99 E-18 \\
1.98 E-18 \\
1.96 E-18 \\
2.01 E-18 \\
1.94 E-18 \\
1.97 E-18 \\
2.00 E-18 \\
1.96 E-18 \\
1.95 E-18 \\
2.15 E-18 \\
1.86 E-18\end{array}$ & $\begin{array}{l}4.4 E-04 \\
3.6 E-04 \\
3.5 E-04 \\
3.5 E-04 \\
3.6 E-04 \\
3.4 E-04 \\
3.4 E-04 \\
3.3 E-04 \\
3.3 E-04 \\
3.3 E-04 \\
3.2 E-04 \\
3.1 E-04 \\
3.1 E-04 \\
3.1 E-04 \\
3.6 E-04 \\
3.1 E-04\end{array}$ \\
\hline
\end{tabular}

F. Sample Number: 1640.9 to 1642.1 After.

Length: $3.101 \mathrm{~cm}$

Volume: $15.72 \mathrm{~cm}^{3}$

Wet Weight: $29.523 \mathrm{~g}$ Dry Weight: $24.984 \mathrm{~g}$

Porosity: 28.9\%

Average Mineral Density: $2.24 \mathrm{~g} / \mathrm{cm}^{3}$

Effective Confining

Pressure

( $\mathrm{PPa}$ )

Permeability Storage Capacity

(ina)

$\left(m^{2}\right)$

(1/MPa)

0.60

2.01E-18

2.9E-04

1.11

1. $79 \mathrm{E}-18$

4. OE-O4

1.68

3.01

3.81

5.31

6.06

6.68

7.29

8.18

8.92

10.43

13.66

17.00

20.26

23.45

26.54

29.41

1.65E-18

3. BE-04

$1.72 \mathrm{E}-18$

$1.62 E-18$

3. 3E-04

1.61E-18

1.61E-18

3.1E-04

3.0E-04

1.64E-18

2. $9 \mathrm{E}-04$

1. 60 E-18

2.9E-04

1.66E-18

2.8E-04

$1.55 \mathrm{E}-18$

1.62E-18

2.8E-O4

2.6E-04

2.7E-04

$1.52 E-18$

1.56E-18

$1.56 \mathrm{E}-18$

2.7E-04

2.5E-04

2.5E-04

$1.62 E \times 18$

$1.57 \mathrm{E}-18$

1.61E-18

2.5E-0.

2.5E-04

2.5E-04

$1.67 \mathrm{E}-18$

2.6E-04 
Sample from 1640.9 to $1642.1 \mathrm{ft}, 120^{\circ} \mathrm{C}, 19.7-\mathrm{MPa}$ confining pressure, $19.7 \mathrm{HPa}$ pore pressure (2.5 months) (test $\# 5$, Table I).

Permeability of both of these samples decreased very slightly after exposure, but the changes are so small as to be insignificant. Storage capacity also remained virtually unchanged.

D. Conclusions

Permeability of the highly zeolitized Calico Hills tuff is essentially unchanged after elevated temperature and pressure exposure for times up to 5.5 months. However, the nonzeolitized, devitrified tuff from the Topopah Spring Member, with nearly the same initial permeability, showed what may be a real permeability increase in as little as 2.5 months. Recall that the major mineralogic changes observed above were dissolution of silica or feldspar minerals in devitrified tuffs but only surface modification of zeolites. These changes are consistent with changes in permeability of samples from the Topopah Spring Member, which consists mostly of silica and feldspar minerals, and lack of changes in the highly zeolitized Calico Hills samples.

The vertical variation in matrix permeability is as large or larger than the changes we observed in side-by-side samples before and after hydrothermal exposure. Therefore, we cannot rule out the possibility that residual sample inhomogeneity is responsible for the apparent changes we observed. Additional testing is needed in which permeability is measured as a function of time in the same sample held at constant temperature and pressure. Some testing of this nature has been performed (Morrow et al.), ${ }^{6}$ but for short timespans $(<1$ month). Further tests of this type would indicate whether any changes noted are real. We believe that the mineralogic reactions identified above will cause changes in hydraulic transport properties of tuff. The important questions are what are the magnitudes and rates of such changes. We cannot answer these questions with certainty based on the results of this exploratory program, but it seems possible to do so with more extensive tests as described above.

V. FINAL SUMMARY AND CONCLUSIONS

The purpose of our test was to explore possible changes in important thermomechanical and transport properties of a range of tuff types from the Yucca Mountain site at NTS after extended exposure to conditions in a rough 
way simulating those expected in the near-field environment of a repository in tuff. These conditions are not mirrored exactly since the temperatures used here generally exceed those expected in a repository. On the other hand, it was necessary to make preliminary interpretations of potential long-term changes on the basis of relatively short experiments, which we accelerated by somewhat higher test temperatures. It should be kept in mind that the thermal pulse of a repository will last for hundreds of years. During this time slow processes of the type we have identified could cause significant changes in the thermomechanical properties of the host rock. These should be taken into account and allowed for through studies of the kinetics of such processes.

We have observed relatively large differences in tensile strength, compressive strength, and permeability between control and altered samples. However, with a few exceptions, porosity and grain density were observed to be unaffected. Thermal properties of these samples were tested by coworkers at Sandia National Laboratories and were also found to be unaffected by the hydrothermal exposure.* Mineralogic and petrologic examination of the test samples indicated the possible operation of reactions involving the jissolution of silica and feldspar, formation of clays, and conversion of clinoptilolite to mordenite. However, we have not been able to establish a one-to-one correlation of mineralogic and structural changes with physical properties changes. Changes in the relative amounts of minerals involved in these reactions were observed to be very small, reflecting the sluggish nature of the reactions. This can explain, in a qualitative way, why some properties were unchanged. For example, thermal properties are dominantly determined by the inherent thermal properties of the constituent mineral phases. Uniess there are substantial changes in the amounts of minerals with significantly different thermal properties, the thermal properties of the rock are not expected to change. We believe that the strength changes we observed are related to the subtle surface modifications of minerals we observed, probably most active along grain boundaries and fracture surfaces where the catalytic action of water is effective. We expect that these same processes will be important in controlling the mechanics of discontinuities such as joints. Indeed, there is evidence that rock friction is time dependent, reflecting viscoplastic processes at point contacts of the surfaces. 7 It thus appears

^Information provided by M. M. Yoss, Sandia National Laboratories (1984). 
that large changes in tuff mechanical properties may result from hydrothermal alteration, without correlated large changes in mineralogy or thermal properties. It is not clear if the rates of strength reduction implied by our tests can be extrapolated to long times.

A quantitative determination of these time-dependent phenomena will require careful measurements on target-horizon tuff samples held at simulated repository conditions for long time periods. For example, it is not known what effects might be anticipated during heating and cooling cycles in unsaturated devitrified tuff such as the Topopah Spring Member, which is the potential host rock at Yucca Mountain. Detailed examination of tested samples should identify the physical-chemical mechanisms involved. In addition, the difficult task of determining the rates of the processes leading to changes in mechanical properties will be required. Once these rates (or at least reasonable estimates) are determined, they can be incorporated in design and performance models to predict or bound the mechanical response of the host rock mass over both the operational time of the repository and after closure.

\section{ACKNOWLEDGMENTS}

The work described here was carried out as part of the NNWSI managed by the Nevada Operations office of the U.S. DOE.

\section{REFERENCES}

1. J. D. Blacic, J. Carter, P. Halleck, P. Johnson, T. Shankland, R. Andersen, K. Spicochi, and A. Heller, "Effects of long-term exposure of tuff to high-level nuclear waste-repository conditions: Preliminary report," Los Alamos National Laboratory report LA-9174-PR, (February 1982).

2. R. W. Spengler, F. M. Byers, and J. B. Warner, "Stratigraphy and structure of volcanic rocks in drill hole USW-G1, Yucca Mountain, Nye County, Nevada," U.S. Geological Survey open-file report 81-1349 (1981).

3. D. L. Bish, F. A. Caporuscio, J. F. Copp, B. M. Crowe, J. D. Purson, J. R. Smyth, and R. G. Warren, "Preliminary stratigraphic and petrologic characterization of core samples from USW-G1, Yucca Mountain, Nevada," Los Alamos National Laboratory report LA-8840-MS (November 1981).

4. F. Caporuscio, D. Vaniman, D. Bish, D. Broxton, B. Arney, G. Heiken, F. Byers, R. Gooley, and E. Semarge, "Petrologic studies of drill cores USW-G2 and UE25b-1H, Yucca Mountain, Nevada," Los Alamos National Laboratory report LA-0?55-MS (July 1982). 
5. J. Y. Tracy Hsieh, C. B. Neuzil, J. D. Bredehoeft, and S. E. Silliman, "A transient laboratory method for determining the hydraulic properties of 'tight' rocks -- I. Theory," Int. J. Rock Mech. Min. Sci. Geomech. Abstr. 18, 245-252 (1981).

6. C. A. Morrow, D. E. Moore, and J. D. Byerlee, "Permeability and pore-fluid chemistry of the Topopah Spring Member of the Paintbrush Tuff, Nevada Test Site, in a temperature gradient-application to nuclear waste storage," Mat. Res. Soc. Symp. Proc. Yol. 26, 883-890 (1984).

7. J. H. Dieterich, "Time-dependent friction and the mechanics of stickslip," Pageoph. 116, 790-806 (1978). 


\section{APPENDIX \\ ELECTRON PROBE ANALYSES OF ZEOLITES AND CLAYS}

TABLE A-I

ZEOLITE ANALYSES

\begin{tabular}{|c|c|c|c|c|c|c|c|}
\hline \multicolumn{5}{|c|}{$\begin{array}{l}\text { Representative zeolite analyses in Callco Hills } \\
\text { sample from the } 1667.3 \text { to } 1668.4 \mathrm{ft} \text { depth of } \\
\text { UE-25ali, before heating. }\end{array}$} & \multicolumn{3}{|c|}{$\begin{array}{l}\text { zeolites in Calice Hills fr } \\
\text { the } 1667.3 \text { to } 1668.4 \text { ft dep } \\
\text { of } \mathrm{VE}-25 \mathrm{i} 1 \text {, before heating }\end{array}$} \\
\hline $\mathrm{SiO}_{2}$ & 64.2 & 66.7 & 63.1 & 63.3 & $510_{2}$ & 69.1 & 68.3 \\
\hline $\mathrm{Al}_{2} \mathrm{O}_{3}$ & 11.2 & 11.5 & 11.2 & 10.8 & $A 3_{2} 0_{3}$ & 12.3 & 11.8 \\
\hline $\mathrm{FeO}^{2}$ & 0.00 & 0.01 & 0.00 & 0.00 & Feo & 0.00 & 0.00 \\
\hline $\mathrm{MgO}$ & 0.00 & 0.00 & 0.00 & 0.00 & $\mathrm{MgO}$ & 0.00 & 0.00 \\
\hline $\mathrm{CaO}$ & 3.70 & 3.51 & 3.46 & 3.47 & $\mathrm{CaO}$ & 4.07 & 3.50 \\
\hline $\mathrm{Ma}_{2} \mathrm{O}$ & 0.47 & 0.95 & 0.78 & 0.79 & $\mathrm{Ma}_{2} \mathrm{O}$ & 0.80 & 1.00 \\
\hline$k_{2}{ }^{c}$ & 2.78 & 3.05 & 2.87 & 2.40 & $k_{2} 0$ & 2.70 & 3.30 \\
\hline BaD & 0.00 & 0.00 & 0.00 & 0.00 & Bá & 0.00 & 0.00 \\
\hline $\boldsymbol{\Sigma}$ & 82.3 & 85.7 & 81.4 & 80.8 & $\Sigma$ & 89.0 & 87.9 \\
\hline si & 14.96 & 14.97 & 14.92 & 15.02 & 51 & 14.91 & 14.97 \\
\hline$A 1$ & 3.07 & 3.05 & 3.11 & 3.01 & AI & 3.12 & 3.04 \\
\hline Itet & 18.03 & 18.02 & 18.03 & 18.03 & rtet & 18.03 & 18.01 \\
\hline $\mathrm{Fe}$ & 0.00 & 0.00 & 0.00 & 0.00 & $\mathbf{F e}$ & 0.00 & 0.00 \\
\hline Mg & 0.00 & 0.00 & 0.00 & 0.00 & Mg & 0.00 & 0.00 \\
\hline $\mathrm{Ca}$ & 0.92 & 0.84 & 0.87 & 0.88 & ca & 0.94 & 0.82 \\
\hline $\mathrm{Na}$ & 0.21 & 0.41 & 0.35 & 0.36 & Ma & 0.33 & 0.42 \\
\hline$k$ & 0.82 & 0.87 & 0.86 & 0.72 & $\mathbf{K}$ & 0.74 & 0.92 \\
\hline Ba & 0.00 & 0.00 & 0.00 & 0.00 & Ba & 0.00 & 0.00 \\
\hline Ilarge & & & & & Ilarge & & \\
\hline cations & 1.95 & 2.12 & 2.08 & 1.96 & cations & 2.01 & 2.16 \\
\hline seations & 19.98 & 20.14 & 20.11 & 19.99 & rcations & 20.04 & 20.17 \\
\hline Ca & 47 & 40 & 42 & 45 & Ca & 47 & 38 \\
\hline Ma & 11 & 19 & 17 & 18 & wa & 16 & 20 \\
\hline $\mathbf{K}$ & 42 & 41 & 41 & 37 & $x$ & 37 & 43 \\
\hline
\end{tabular}


Zeulftes in calico

Hills from the 1667.3

to $1668.4 \mathrm{ft}$ depth of

UE-25all, ofter $120^{\circ} \mathrm{C}$

for 2.5 months (Test

45. Table 11.

Somple Center

$\begin{array}{lc}\mathrm{S1O}_{2} & 68.2 \\ \mathrm{AT}_{2} \mathrm{O}_{3} & 12.4 \\ \mathrm{FeO}_{3} & 0.00 \\ \mathrm{MgO} & 0.00 \\ \mathrm{CaO} & 4.29 \\ \mathrm{Ma}_{2} \mathrm{O} & 0.85 \\ \mathrm{~K}_{2} \mathrm{O} & 2.38 \\ \mathrm{BaO} & 0.00 \\ \mathrm{~L} & \mathrm{Bg} .1\end{array}$

$51 \quad 14.84$

A) $\quad 3.19$

Itet $\quad 18.03$

Fe $\quad 0.00$

Mg 0.00

Ca $\quad 1.00$

Na $\quad 0.36$

K $\quad 0.66$

$\mathrm{Ba} \quad 0.00$

Ilarge

$\begin{array}{rr}\text { cations } & 2.02 \\ \text { ceations } & =20.05\end{array}$

Ca 50

Ma 18

K 33 2eolites in Caltco Hills from the 1667.3

to $1668.4 \mathrm{ft}$ depth of UE-25a/1, after wealing at $120^{\circ} \mathrm{C}$ for 2.5 months (Test 15. Table 1 ).

\begin{tabular}{|c|c|c|c|}
\hline \multirow{4}{*}{$\begin{array}{l}\mathrm{S1O}_{2} \\
\mathrm{Al}_{2} \mathrm{O}_{3} \\
\mathrm{FeO}\end{array}$} & \multicolumn{3}{|c|}{ Sample Center } \\
\hline & 68.8 & 66.5 & 68.2 \\
\hline & 12.3 & 12.0 & 11.4 \\
\hline & 0.00 & 0.00 & 0.00 \\
\hline $\mathrm{MgO}$ & 0.00 & 0.00 & 0.00 \\
\hline $\mathrm{CaO}$ & 3.92 & 4.02 & 3.50 \\
\hline $\mathrm{Na}_{2} \mathrm{O}$ & 0.79 & 0.88 & 0.96 \\
\hline $\mathrm{K}_{2} \mathrm{O}$ & 2.71 & 2.31 & 2.75 \\
\hline 800 & 0.00 & 0.00 & 0.00 \\
\hline 2 & 88.6 & 85.7 & 86.9 \\
\hline Si & 14.90 & 14.88 & 15.05 \\
\hline A1 & 3.14 & 3.17 & 2.97 \\
\hline$\varepsilon$ tet & 18.04 & 18.05 & 18.02 \\
\hline Fe & 0.00 & 0.00 & 0.00 \\
\hline mg & 0.00 & 0.00 & 0.00 \\
\hline Ca & 0.91 & 0.96 & 0.82 \\
\hline Ma & 0.32 & 0.37 & 0.41 \\
\hline $\mathbf{k}$ & 0.74 & 0.65 & 0.77 \\
\hline Ba & 0.00 & 0.00 & 0.00 \\
\hline
\end{tabular}

Elarge

$\begin{array}{llll}\text { cations } & 1.97 & 1.99 & 2.00\end{array}$

rcations

20.01

20.04

20.02

ca

46

48

41

wa

16

19

20

K

38

33

39 
Zeolites in Calico Hills from the 1667.3 to $1668.4 \mathrm{ft}$ depth of UE-25af1, after heating at $120^{\circ} \mathrm{C}$ for 2.5 months (Test $* 5$. Table I).

Sample Center Samole Rim

$\begin{array}{lccc}\mathrm{SHO}_{2} & 68.4 & 66.2 & 67.2 \\ \mathrm{Al}_{2} \mathrm{O}_{3} & 12.1 & 10.9 & 11.9 \\ \mathrm{FeO} & 0.00 & 0.19 & 0.00 \\ \mathrm{MgO} & 0.00 & 0.00 & 0.00 \\ \mathrm{CaO} & 3.82 & 3.30 & 3.57 \\ \mathrm{Ha}{ }_{2} \mathrm{O} & 1.01 & 0.66 & 1.23 \\ \mathrm{~K} \mathrm{O}_{2} & 2.61 & 2.77 & 2.56 \\ \mathrm{BaO} & 0.00 & 0.00 & 0.00 \\ \Sigma & 88.0 & 84.0 & 86.5 \\ & & & \\ \mathrm{Si} & 14.93 & 15.11 & 14.93 \\ \mathrm{Al} & 3.10 & 2.92 & 3.11 \\ \Sigma \text { tet } & 18.03 & 18.03 & 18.04 \\ \mathrm{Fe} & 0.00 & 0.03 & 0.00 \\ \mathrm{Mg} & 0.00 & 0.00 & 0.00 \\ \mathrm{Ca} & 0.89 & 0.80 & 0.85 \\ \mathrm{Ha} & 0.42 & 0.29 & 0.53 \\ \mathrm{~K} & 0.72 & 0.80 & 0.72 \\ \mathrm{Ba} & 0.00 & 0.00 & 0.00\end{array}$

Elarge

$$
\text { cations } 2.03 \quad 1.92
$$$$
2.10
$$$$
\Sigma \text { cations } 20.06 \quad 19.95
$$$$
20.14
$$

Ca

$$
44 \quad 42
$$

40

Na

K

25

34
Zeolites in Calico Mllis from the 1667.3 to $1668.4 \mathrm{ft}$ deoth of UE-25a 1 , efter heating at $120^{\circ} \mathrm{C}$ for 2.5 months (Test

5. Table I).

Sample Rim

$\mathrm{StO}_{2}$
$\mathrm{Al}_{2} \mathrm{O}_{3}$

65.9

11.4

Feo

0.03

MgO

0.00

caO

3.87

$\mathrm{Ha}_{2} \mathrm{O}$

0.96

$\mathrm{K}_{2} \mathrm{O}$

2.07

BaO

0.00

$\boldsymbol{\Sigma}$

84.2

S1

14.96

A1

3.06

rtet

18.02

Fe

0.00

Mg

0.00

ca

0.94

Ha

0.42

K

0.59

Ba

0.00

zTarge

cations

1.95

zcations

19.97

ca

48

Aa

22

K

30 
TABLE A-I (cont)

Zeolttes in Calfeo Hflls from the 1667.3 to

$1668.4 \mathrm{ft}$ depth of UE-25alls ofter $180^{\circ} \mathrm{C}$ for 3.5 wonths (Test 17. Tabie i).

\begin{tabular}{|c|c|c|c|c|}
\hline 510 & 62.2 & 65.5 & 69.3 & 63.8 \\
\hline & 11.1 & 12.1 & 12.0 & 10.7 \\
\hline$F \times 0^{\circ}$ & 0.01 & 0.03 & 0.00 & 0.00 \\
\hline $\mathrm{MgO}$ & 0.00 & 0.00 & 0.00 & 0.00 \\
\hline $\mathrm{CaO}$ & 3.42 & 3.82 & 3.90 & 3.68 \\
\hline & 0.76 & 1.03 & 1.27 & 0.69 \\
\hline $\mathrm{K}_{2} \mathrm{O}$ & 2.30 & 2.69 & 2.50 & 2.16 \\
\hline Bab & 0.63 & 0.00 & 0.100 & 0.00 \\
\hline $\boldsymbol{t}$ & 80.4 & 85.2 & 89.4 & 81.0 \\
\hline \$1 & 14.92 & 14.81 & 14.92 & 15.06 \\
\hline A1 & 3.14 & 3.22 & 3.05 & 2.97 \\
\hline Itet & 18.06 & 18.03 & 17.97 & 18.03 \\
\hline Fe & 0.00 & 0.00 & 0.00 & 0.00 \\
\hline$M g$ & 0.00 & 0.00 & 0.00 & 0.00 \\
\hline $\mathrm{Ca}$ & 0.87 & 0.92 & 0.90 & 0.93 \\
\hline Ma & 0.35 & 0.45 & 0.52 & 0.31 \\
\hline$k$ & 0.70 & 0.78 & 0.80 & 0.65 \\
\hline Ba & 0.06 & 0.00 & 0.00 & 0.00 \\
\hline
\end{tabular}

riarge

$\begin{array}{lllll}\text { cattons } & 1.98 & 2.15 & 2.22 & 1.89\end{array}$

Ications $20.04 \quad 20.18 \quad 20.19 \quad 19.92$

$\begin{array}{lllll}\mathrm{C} & 45 & 43 & 40 & 49 \\ \mathrm{Na} & 18 & 21 & 24 & 16 \\ \mathrm{~K} & 36 & 36 & 36 & 34\end{array}$

zeotites in colico

Hitls from the 1657.3 to 1658.4 ft depth of UE-25el1, after $100^{\circ} \mathrm{C}$ for 3.5 inonths (Test 17. Toble I).

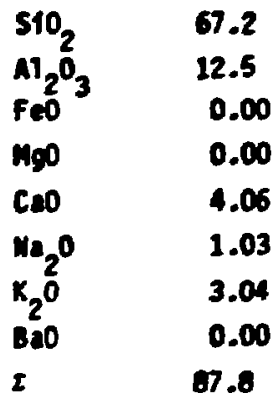

St

14.76

A1

3.24

ztet 18.00

fe 0.00

$\mathrm{Mg} \quad 0.00$

Ca 0.95

Un 0.43

k 0.84

8 0.00

ETorge

cations 2.22

reations 20.22

$\begin{array}{ll}\text { Ca } & 43 \\ \times & 20 \\ \times & 38\end{array}$


TABLE A-II

CLAY ANALYSES

Clay analyses in Bullfrog sample from the 2380.6 to $2381.2 \mathrm{ft}$ deptn of USW G-1, ofter soaking in $\mathrm{J}-13$ well water at $180^{\circ} \mathrm{C}$ for 3.5 months (Test 18 . Table I).

$\begin{array}{lccccc}\mathrm{SHO}_{2} & 55.0 & 59.7 & 55.9 & 56.3 & 55.4 \\ \mathrm{THO}_{2} & 0.02 & 0.01 & 0.09 & 0.00 & 0.04 \\ \mathrm{Al}_{2} \mathrm{O}_{3} & 21.6 & 23.0 & 21.7 & 21.6 & 22.0 \\ \mathrm{FeO}^{2} & 3.70 & 4.26 & 4.41 & 4.24 & 3.80 \\ \mathrm{MnO} & 0.20 & 0.17 & 0.25 & 0.19 & 0.20 \\ \mathrm{MgO} & 2.16 & 2.37 & 2.22 & 2.39 & 2.20 \\ \mathrm{CaO} & 1.37 & 1.45 & 1.40 & 1.52 & 1.46 \\ \mathrm{Ma}_{2} \mathrm{O} & 1.77 & 2.20 & 1.84 & 1.92 & 1.83 \\ \mathrm{~K}_{2} \mathrm{O} & 0.44 & 0.31 & 0.53 & 0.44 & 0.61 \\ \Sigma & 86.2 & 93.5 & 88.4 & 88.5 & 87.4\end{array}$

$\begin{array}{llllll}\text { S1 } & 7.64 & 7.67 & 7.63 & 7.65 & 7.61\end{array}$

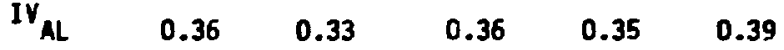

$\begin{array}{lllllll}\text { Etet } & 8.00 & 8.00 & 8.00 & 8.00 & \mathbf{8 . 0 0}\end{array}$

$\begin{array}{llllll}V_{\text {AL }} & 3.18 & 3.16 & 3.13 & 3.11 & 3.26\end{array}$

$\begin{array}{llllll}\text { Ti } & 0.00 & 0.00 & 0.01 & 0.00 & 0.00\end{array}$

$\begin{array}{llllll}\text { Fe } & 0.43 & 0.46 & 0.50 & 0.47 & 0.44\end{array}$

$\begin{array}{llllll}\text { Mn } & 0.02 & 0.01 & 0.03 & 0.02 & 0.02\end{array}$

$\begin{array}{llllll}\mathrm{Mg} & 0.44 & 0.45 & 0.45 & 0.48 & 0.45\end{array}$

$\begin{array}{llllll}\text { loct } & 4.10 & 4.08 & 4.11 & 4.08 & 4.07\end{array}$

$\begin{array}{llllll}\text { ca } & 0.20 & 0.20 & 0.20 & 0.22 & 0.21\end{array}$

$\begin{array}{llllll}\text { Ha } & 0.47 & 0.55 & 0.48 & 0.51 & 0.49\end{array}$

$\begin{array}{llllll}K & 0.08 & 0.05 & 0.09 & 0.08 & 0.10\end{array}$

Inter-

$\begin{array}{llllll}\text { layer } & 0.75 & 0.80 & 0.77 & 0.81 & 0.80\end{array}$ 